\title{
Metabolic Parameters in Obese Dogs Undergoing to the Diet with Calorie Restriction
}

\author{
Paula Nassar de Marchi' ${ }^{1}$, Mauro José Lahm Cardoso ${ }^{2}$, Rafael Fagnani ${ }^{3}$, \\ Jéssica Ragazzi Calesso4, Maíra Melussi'5, Luiz Henrique de Araújo Machado1 \\ ${ }^{1}$ College of Veterinary Medicine and Zootechnics, Júlio de Mesquita Filho (UNESP/Botucatu), Botucatu, Brazil \\ ${ }^{2}$ Department of Veterinary Clinics, State University of Londrina (UEL), Londrina, Brazil \\ ${ }^{3}$ University of North of Paraná, Londrina, Brazil \\ ${ }^{4}$ Veterinary Hospital, State University of Northern Parana (UENP/Campus Luiz Meneghel), Bandeirantes, Brazil \\ ${ }^{5}$ Veterinarian at Clinic Space Life (Londrina-PR), Londrina, Brazil \\ Email: paula_nassar@yahoo.com.br
}

How to cite this paper: de Marchi, P.N., Cardoso, M.J.L., Fagnani, R., Calesso, J.R., Melussi, M. and de Araújo Machado, L.H. (2018) Metabolic Parameters in Obese Dogs Undergoing to the Diet with Calorie Restriction. Open Journal of Veterinary Medicine, 8, 25-35.

https://doi.org/10.4236/ojvm.2018.83004

Received: December 14, 2017

Accepted: March 24, 2018

Published: March 27, 2018

Copyright (C) 2018 by authors and Scientific Research Publishing Inc. This work is licensed under the Creative Commons Attribution International License (CC BY 4.0).

http://creativecommons.org/licenses/by/4.0/

\begin{abstract}
Currently, canine obesity is a worldwide problem and is based on the excessive deposit of fat tissue, which plays an important role as a store of energy and endocrine organ. This study aimed to compare the values of systolic blood pressure, serum chemistry profile and glucose metabolism in eight obese dogs without endocrine diseases before and after 16 weeks of a weight loss program. A statistical difference was noticed in the serum levels of alkaline phosphatase, gamma glutamyl transferase, glucose, cholesterol and insulin, before and after the program. Besides, there was a statistical difference between the moments in systolic blood pressure, body weight and body condition scale. Therefore, it was concluded that the use of a diet rich in fiber and protein is suitable for performing weight loss and obese dogs undergoing a weight loss program presented a significant reduction in blood pressure, blood glucose, insulin, blood cholesterol, serum activity of alkaline phosphatase and gamma glutamyl transferase.
\end{abstract}

\section{Keywords}

Arterial Hypertension, Canine, Insulin Resistance, Obesity

\section{Introduction}

Canine obesity is a worldwide problem, estimating that at least $30 \%$ to $40 \%$ of the world's canine population being obese [1]. Obesity is an accumulation of adipose tissue, which works as a deposit of energy and as an endocrine organ [2] [3]. Obesity occurs when there is a prolonged positive energy balance, when the 
calorie intake is higher than the energy spent. Further, it may be related to excess calorie intake, sedentary lifestyle, endocrine diseases and some medications [2]. In humans, a number of changes due obesity are well documented as musculoskeletal disorders, cardiovascular, respiratory, insulin resistance, exercise and heat intolerance, hyperlipidemia (increased of triglycerides and cholesterol), dermatopathies, neoplasms, increased anesthetic risk and predisposition to arterial hypertension, atherosclerosis and type 2 diabetes mellitus [4]. In these species it is clear that visceral obesity is a risk factor for the development of type 2 diabetes mellitus, for a condition called insulin resistance (IR). IR is a failure of target cells in peripheral tissues to use insulin and maintain a euglycemia response despite normal circulating insulin levels, thus requiring insulin secretion to increase in order to achieve the appropriate physiological response [4]. In the same way, in cats, obesity results in IR, predisposing them to the development of diabetes mellitus like type 2 of humans [5]. However, in dogs, the direct relationship between obesity and the development of hypertension and insulin resistance, predisposing to type 2 diabetes mellitus like in humans is not proven, although there are several works in the literature [6] [7]. The major difficulty of treatment of obese dogs is an acceptance and awareness of the owner [8]. The successful key in obesity treatment is an institution of proper diet, calorie restriction and regular practice of physical activity. For faster and more effective weight loss, the amount of calories should be calculated based on a calorie restriction factor rather than of the maintenance [9]. The ideal diet to be chosen is the one with more fiber and protein, because it provides better and faster weight loss when compared to diets with high protein and medium fiber [10] [11]. Several studies have demonstrated that high-protein and high-fiber diets provide a greater sense of satiation to dogs and promote effective weight loss in obese dogs [9] [10] [11]. In addition, some authors notice that weight loss reduces SBP, triglyceride, cholesterol, glycemia and insulin levels [5] [6] [7]. The objectives of the present study evaluated the values of systolic blood pressure (SBP), serum biochemical profile and glucose metabolism in eight obese dogs nonendocrinopaths before and after being submitted to the sixteen week weight loss program.

\section{Material and Methods}

The samples were originated of animals from a private practice and a Veterinary Hospital from a University. All the owners signed a free and informed consent form, authorizing the collection of materials and use of the data in publications. In addition, the project (number 2335) was approved by the Ethics Committee on Animal Use on October $10^{\text {th }}, 2011$.

Selection and Number of Animals: Body condition was measured according to the 1 - 9 Body Condition Score System (BCS) [12]. Only three trained examiners did the BCS assessment, strictly following the description of scale 1 - 9. Thus, dogs with body score 8 and 9 of 9 were considered obese, while dogs with body score 6 and 7 of 9 were considered overweight [12]. 
17 dogs participated in this study, yet only eight dogs remained during the program. The others gave up on the diet or did not attend the expected returns. The dogs had body score 8 and 9 on a 9-point body condition scale, suggested by [12]. The dogs have weighed always on the same scale and had their body condition scale determined at different moments: M0, initial moment and M1, after 16 weeks of the diet. The animal's body score was measured according to the 9-point body condition scale described by [12].

Exclusion factors of the study were animals with endocrinopathies (diabetes mellitus, hyperadrenocorticism, and hypothyroidism), heart diseases, liver diseases and nephropathies. Also, excluded were those who did not adhere to the diet program or were being medicated with glucocorticoids (systemic or topical), anticonvulsants, hypo or hyperglycemic drugs and hypotensive drugs (furosemide, angiotensin converting enzyme inhibitors, pimobendan and amlodipine). Hyperadrenocorticism was ruled out by the low-dose dexamethasone suppression test (two collections), described by [13]. To exclude hypothyroidism, total thyroxine (TT4), free thyroxine (FT4) and canine thyroid stimulating hormone (cTSH) were measured. Clinical examination and hemogram, urinalysis and serum biochemical profile were used to rule out cardiac, renal and hepatic diseases.

The blood samples to obtain serum were taken in a 12-hour fasting meal, five $\mathrm{mL}$ of blood were collected from the jugular vein, which was placed in tubes containing clot activator gel and centrifuged at $2000 \times$ turns for 10 minutes within one hour after collection. Then, the serum obtained was fractionated in five $1.2 \mathrm{~mL}$ vials for freezing at $-70^{\circ} \mathrm{C}$ until the tests were performed. Samples for glucose measurement were obtained in a tube containing sodium fluoride. Samples were used for the measurement of glucose, urea, creatinine, alanine aminotransferase (ALT), gamma glutamyl transferase (GGT), total protein, albumin, alkaline phosphatase (ALKP), triglycerides and cholesterol, by colorimetric enzymatic or kinetic methodology, following the manufacturer's recommendations. The results were read and obtained with an automatic analyzer (Catalyst One Chemistry Analyzer, IDEXX Laboratories ${ }^{\circledR}$, USA).

The measurement of serum concentrations of total thyroxine (TT4), canine thyroid stimulating hormone (cTSH), cortisol and free thyroxine (FT4) were realized by equilibrium dialysis using the radioimmunoassay technique in the laboratory B.E.T. Laboratories (Rio de Janeiro, RJ). Serum insulin measurement was performed by radioimmunoassay at Provet Laboratory (São Paulo, SP), using recommendations from the manufacturer, with intraassay and interassay sensitivity, respectively, of $3.23 \%$ and $3.65 \%$. Samples were measured in duplicate.

Non-Invasive Systolic Blood Pressure (SBP) was obtained by the non-invasive method using the Doppler flowmeter, as described by [14]. The cuffs were selected according to the diameter of the limb $(40 \%$ of the circumference of the limb). The finding of arterial hypertension was based on average levels of SBP above $150 \mathrm{mmHg}$, after three consecutive measurements [15]. 
For the calculation, the desired weight was estimated, which was 30\% lower than the initial weight of each dog. To calculate the energy requirement, the following formula was used: $70 \mathrm{kcal} \times(\text { Desired Weight })^{0.75}=\mathrm{kcal}$ daily [16]. The daily grams value was obtained by dividing the daily kcal value by the metabolizable energy value of the selected diet. The 16-week interval was defined based on the maximum allowable loss of $2 \%$ per week [17], thus, if the animals reached the maximum weekly allowable loss the ideal weight would be achieved in up to 16 weeks.

The animals were weighed at M0 and monthly during 16 weeks. The BCS, SBP and serum parameters were analyzed only in the M0 and M1. The diet selected was a specific commercial diet for weight loss (Farmina ${ }^{\circledR}$ Obesity and Diabetic), with a metabolizable energy value of $2950 \mathrm{kcal} / \mathrm{kg}$ and protein and fiber contents of $22 \%$ and $7.8 \%$, respectively (Table 1 ). It is considered a diet with high protein and fiber composition when compared to non-support diets for healthy adult dogs.

The experimental design weighted the possible differences before (M0) and after 16 weeks (M1) on serum levels of urea, creatinine, ALT, ALKP, GGT, glucose, cholesterol, triglycerides, albumin, total protein (TP), SBP, insulin, body weight and BCS. The variables did not present normality and homocedasticity by the Kolmogorov-Smirnov test and Liliefors test $(\mathrm{P}<0.05)$. Thus, the differences between groups were evaluated in pairs by the Wilcoxon test, with $\mathrm{P}<$ 0.05 .

\section{Results}

From the animals that started the hypocaloric diet, only eight (47.06\%) were followed during program. Being five females and three males, three dogs without breed, two Schnauzer, one Pomeranian, one Lhasa Apso and one Yorkshire Terrier. The ages of the dogs ranged from four to eight years old.

The results of the analyzed parameters are described in Table 2 and Table 3. The serum values of GGT, glucose, cholesterol, ALKP, and insulin presented average difference $(\mathrm{P}<0.05)$ between $\mathrm{M} 0$ and M1. It was also observed the difference in the average before and after weight loss $(\mathrm{P}<0.05)$ in SBP, body weight and BCS.

All animals studied were considered obese at the time of the initial study (M0), and 50\% were classified with a body condition score (BCS) 9/9, which

Table 1. Nutritional information of the composition of Farmina ${ }^{\circledR}$ Obesity and Diabetic.

\begin{tabular}{cc}
\hline Umidity (max) & $100 \mathrm{~g} / \mathrm{kg}(10 \%)$ \\
Crude Protein (min) & $220 \mathrm{~g} / \mathrm{kg}(22 \%)$ \\
Ethereal Extract/Fat (min) & $70 \mathrm{~g} / \mathrm{kg}(7 \%)$ \\
Fibrous Matter (max) & $78 \mathrm{~g} / \mathrm{kg}(7.8 \%)$ \\
Mineral Matter (max) & $75 \mathrm{~g} / \mathrm{kg}(7.5 \%)$ \\
Metabolizable Energy & $2950 \mathrm{kcal} / \mathrm{kg}$ \\
\hline
\end{tabular}


Table 2. Body weight and body condition scale values in eight dogs submitted to calorie restricted diet for 16 weeks.

\begin{tabular}{ccccc}
\hline & \multicolumn{2}{c}{ BW kg } & \multicolumn{2}{c}{ BCS } \\
\cline { 2 - 5 } & M0 & M1 & M0 & M1 \\
\hline Average $^{*}$ & $12.17^{\mathrm{a}}$ & $9.41^{\mathrm{b}}$ & $8.5^{\mathrm{a}}$ & $6.38^{\mathrm{b}}$ \\
Minimum & 3.9 & 3.1 & 8 & 6 \\
Maximum & 17.4 & 13.9 & 9 & 7 \\
Standard Deviation & 4.4 & 3.35 & 0.53 & 0.52 \\
Standard Error & 1.55 & 1.18 & 0.19 & 0.18 \\
P Value & 0.01 & & 0.01 & \\
\hline
\end{tabular}

BW $(\mathrm{kg})=$ body weight, $\mathrm{BCS}=$ body score condition. M0-initial moment, M1-after 16 weeks. A, b: Means followed by letters ${ }^{*} \mathrm{a}, \mathrm{b}$ did not differ in the Kolmogorov-Smirnov test and the Liliefors T-test with $0.5 \%$ significance; ${ }^{*} \mathrm{~A}, \mathrm{~b}$ Means followed by equal letters did not differ in the Wilcoxon paired test with $0.5 \%$ significance.

Table 3. Serum biochemical profile, insulin, and SBP in eight dogs submitted to calorie restricted diet for 16 weeks.

\begin{tabular}{|c|c|c|c|c|}
\hline & \multicolumn{2}{|c|}{ Average \pm SD (Interval) } & \multirow{2}{*}{ P Value } & \multirow{2}{*}{ Reference } \\
\hline & M0 & M1 & & \\
\hline Urea & $\begin{array}{c}34.53 \pm 10 \\
(19.3-46.9)\end{array}$ & $\begin{array}{l}46.51 \pm 9.32 \\
(33.9-59.8)\end{array}$ & 0.09 & $21.4-59.92 \mathrm{mg} / \mathrm{dL}$ \\
\hline Creatinine & $\begin{array}{c}0.95 \pm 0.21 \\
(0.6-1.3)\end{array}$ & $\begin{array}{c}0.99 \pm 0.26 \\
(0.7-1.5)\end{array}$ & 0.61 & $0.5-1.5 \mathrm{mg} / \mathrm{dL}$ \\
\hline ALT & $\begin{array}{c}37.88 \pm 16.66 \\
(12-62.3)\end{array}$ & $\begin{array}{c}48.44 \pm 18.06 \\
(27.8-77.3)\end{array}$ & 0.26 & $21-73 \mathrm{UI} / \mathrm{L}$ \\
\hline ALKP & $\begin{array}{c}200.99 \pm 101.47 \\
(55.8-370.6)\end{array}$ & $\begin{array}{c}129.11 \pm 64.5 \\
(48-233.5)\end{array}$ & 0.05 & $20-156 \mathrm{UI} / \mathrm{L}$ \\
\hline GGT & $\begin{array}{c}5.46 \pm 2.54 \\
(1.7-9)\end{array}$ & $\begin{array}{c}2.72 \pm 1.95 \\
(0.3-5.1)\end{array}$ & 0.05 & $1.2-6.4 \mathrm{UI} / \mathrm{L}$ \\
\hline $\mathrm{TP}$ & $\begin{array}{c}7.58 \pm 0.63 \\
(7-8.8)\end{array}$ & $\begin{array}{c}7.49 \pm 0.77 \\
(6.3-8.4)\end{array}$ & 0.67 & $5.4-7.1 \mathrm{~g} / \mathrm{dL}$ \\
\hline Albumin & $\begin{array}{l}2.69 \pm 0.32 \\
(2.4-3.38)\end{array}$ & $\begin{array}{c}2.35 \pm 0.39 \\
(1.5-2.7)\end{array}$ & 0.11 & $2.6-3.3 \mathrm{~g} / \mathrm{dL}$ \\
\hline Glucose & $\begin{array}{c}125.58^{\mathrm{a}} \pm 17.56 \\
(100-151)\end{array}$ & $\begin{array}{c}84.11^{\mathrm{b}} \pm 9.57 \\
(69-96.9)\end{array}$ & 0.01 & $70-110 \mathrm{mg} / \mathrm{dL}$ \\
\hline Cholesterol & $\begin{array}{l}336.76^{a} \pm 50.8 \\
(264.4-397.4)\end{array}$ & $\begin{array}{c}185.31^{\mathrm{b}} \pm 31.18 \\
(117-214.9)\end{array}$ & 0.01 & $168.1-268.4 \mathrm{mg} / \mathrm{dL}$ \\
\hline Triglycerides & $\begin{array}{c}311.88^{\mathrm{a}} \pm 61.16 \\
(235.2-388.7)\end{array}$ & $\begin{array}{c}268.19^{b} \pm 65.75 \\
(119.1-324.2)\end{array}$ & 0.09 & $16.81-96.1 \mathrm{mg} / \mathrm{dL}$ \\
\hline Insulin & $\begin{array}{l}24.74^{\mathrm{a}} \pm 12.02 \\
(12.92-50.44)\end{array}$ & $\begin{array}{c}19.37^{\mathrm{b}} \pm 7.96 \\
(11.36-33.86)\end{array}$ & 0.01 & $20-40 \mu \mathrm{U} / \mathrm{mL}$ \\
\hline SBP & $\begin{array}{c}158.63^{\mathrm{a}} \pm 20.70 \\
(130-195)\end{array}$ & $\begin{array}{c}134.63^{\mathrm{b}} \pm 17.74 \\
(119-175)\end{array}$ & 0.01 & $90-160 \mathrm{mmHg}$ \\
\hline
\end{tabular}

A, b: Means followed by equal letters did not differ in the Kolmogorov-Smirnov test and the Liliefors T-test with $0.5 \%$ significance; ${ }^{\star} \mathrm{A}, \mathrm{b}$ Means followed by equal letters did not differ in the Wilcoxon paired test with $0.5 \%$ significance. Statistical difference in M0 and M1 $(\mathrm{P}<0.05)$, M0-initial moment, M1-after 16 weeks. ALT = alanine aminotransferase, ALKP = alkaline phosphatase, GGT = gamma glutamyl transferase, $\mathrm{TP}=$ total protein, $\mathrm{SBP}=$ systolic blood pressure. 
means pronounced obesity, and the others classified with BCS 8/9. After completing the 16 weeks weight loss program (M1), all of them reached the overweight body score, where five of the eight animals studied reached the BCS 6/9 and three animals the BCS 7/9.

The dogs presented an average reduction in weight of $22.7 \%$ in 16 weeks, which means $1.42 \%$ per week (Figure 1). There was a significant reduction of BCS, cholesterol, triglycerides, SBP, glucose, and insulin between M0 and M1 (Figure 1 and Figure 2).
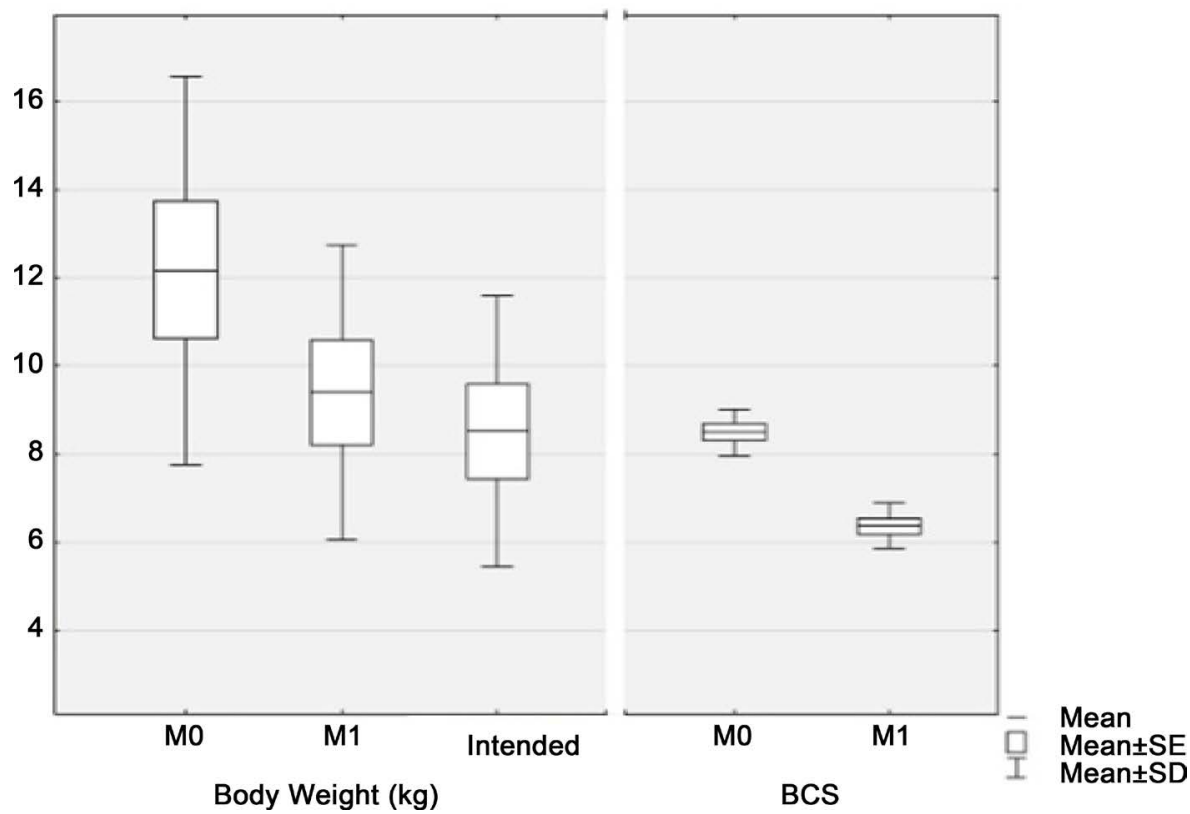

Figure 1. Means, standard error (SE) and standard deviation (SD) of body weight and body condition scale (BCS) of 8 dogs on a calorie restricted diet. M0—initial moment; M1—after 16 weeks.
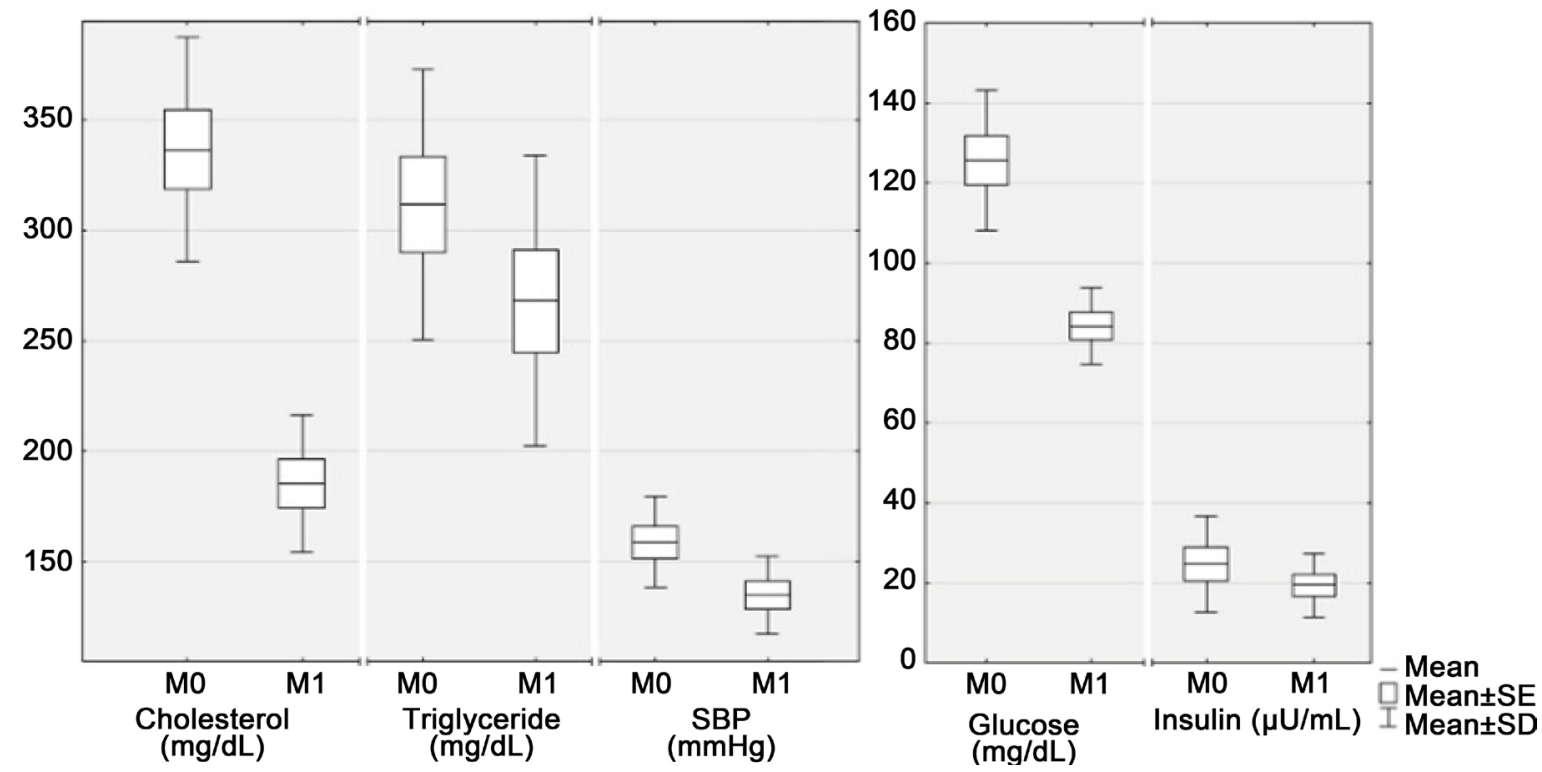

Figure 2. Means, standard error (SE) and standard deviation (SD) of cholesterol, triglycerides and systolic blood pressure (SBP), glucose and insulin of 8 dogs on a calorie restricted diet. M0-initial moment; M1-after 16 weeks. 


\section{Discussion}

The diet was calculated from a calorie restriction of $25 \%$ of the normal calorie intake of each patient based on the reduction of $30 \%$ from the initial weight. Weight loss was considered satisfactory (1.42\%/week) based on the loss of at least $1 \%$ and at most $2 \%$ of the initial weight per week and considering the total time of program. Two animals presented loss of less than $1 \%$ from the initial weight per week, and in these cases, is indicate a reduction of the daily calorie intake in further $10 \%$ and reassessment of the management in order to detect failures in the diet [17]. The diet used was a commercial product with high fiber and protein when compared to the conventional products of the same brand. These results are similar to the findings by [11] that also detected satisfactory weight loss when using high fiber and protein diets in obese dogs. However, weight loss in the current study was superior to that found by [9] and [7], where the dogs had an average loss of $0.85 \% \pm 0.344 \%$ per week. The data differed because in one of the studies the owners abandoned the diet or confessed to providing snacks during the study [9], a fact that in the eight followed dogs for 16 weeks was not reported in this study.

There was systolic arterial hypertension (SAH) in 50\% of the obese dogs, considering a reference value higher or equal to $150 \mathrm{mmHg}$ [15]. However, only one dog had SBP value in the range considered a serious risk to the development of target organ damage [15]. There was a reduction of SBP in the eight dogs after the hypocaloric diet, demonstrating that there is a benefit of weight loss over cardiovascular function. In addition, only one of the four animals with hypertension remained hypertensive after weight loss. Furthermore, these findings corroborate other studies in which obese dogs that lost at least $15 \%$ of their initial weight had a significant fall in SBP [6] [7] [18]. Differently from the present study, none obese hypertensive dog was detected by [6] and [19]. However, in another study, it was demonstrated that dogs submitted to hypercaloric diets and fast weight gain showed increase in the heart rate and SBP [20]. The reason for these differences was probably the inclusion and exclusion factors of the studies. In the dogs included in this study there were no changes in target organs, secondary to SAH [21].

There was a significant $(\mathrm{P}<0.05)$ reduction in serum triglyceride and cholesterol concentrations between M0 and M1, however, the cholesterol reduction was greater after 16 weeks of diet. Reference [22] found similar results when initiating a low calorie diet in a group of obese dogs, but triglyceride levels reduced more significantly than cholesterol levels without weight loss. In general, obese dogs exhibit increased levels of triglycerides and cholesterol when compared to dogs with adequate body score, and it tends to be reduced after caloric restriction diet [7] [23].

ALKP and GGT fell significantly after the 16 week weight loss program, and the detection of the increased serum ALKP activity in obese dogs has been described previously [24]. Although there are a few studies in this regard, it is spe- 
culated that the reduction of ALKP and GGT values may be directly related to the reduction of hyperlipidemia, since they are enzymes present in bile ducts that tend to increase their serum concentrations in the occurrence of biliary cholestasis and mucocele [25]. In addition, intense hyperlipidemia may cause false laboratory increase of ALKP [26], which did not occur in this study.

The values of glucose and insulin reduced significantly between M0 and M1 $(\mathrm{P}<0.01)$. Considering hyperglycemia values of glucose higher than $110 \mathrm{mg} / \mathrm{dL}$ [23], it was verified that $75 \%$ of the dogs studied were hyperglycemic while obese, a situation that was reversed after weight loss, corroborating with the findings of [18]. These authors did not detect hyperglycemia in obese dogs but observed a significant reduction of serum glucose values after weight loss. Our findings corroborate other studies, which have shown an improvement in IR in obese dogs submitted to weight loss [22] [27] [28]. Obese dogs tend to have higher blood levels of serum glucose and insulin when compared to skinny dogs [7] [23] [27] [28]. In contrast, other authors did not find higher glucose values in obese dogs when compared to older dogs or skinny adults [29]. However, in spite of euglycemia, hyperinsulinemia was detected in obese dogs, suggesting the occurrence of IR [22] [30]. Only one of the eight obese dogs studied had hyperinsulinemia, which means, insulin greater than $40 \mu \mathrm{U} / \mathrm{mL}$ [27]. In spite of this, all dogs showed a reduction of about $22 \%$ of insulinemia after weight loss, similar to the findings from [7]. Probably obesity in dogs causes metabolic alterations in glycemic homeostasis and the sensitivity of peripheral tissues to the action of insulin, requiring the secretion of greater amounts of insulin to maintain glycemia at normal or in upper limit values [22] [23] [27] [29]. Reference [29] consider that although there is IR in obese dogs, they have compensatory mechanisms that act to maintain euglycemia and, therefore, dogs do not develop diabetes mellitus similar to type 2 as occurs in humans. This concept is still very controversial, but it is a fact that obesity does influence the amount of insulin secreted. Reference [23] notices a considerable increase in serum insulin concentrations and pancreatic B cell function in obese dogs, in spite of the maintenance of euglycemia. Reference [24] did not identify any changes in glucose and insulin index. However, the authors suggest that it probably occurred due to the degree of adiposity, which means, the animals studied were overweight and not obese, which corroborates our work, where overweight dogs (M1) showed no signs of IR as observed in the obese dogs.

Our study presents some limitations, such as not having studied the dogs at a third moment after each dog reached its ideal weight and the small number that remained in the study during the program.

We concluded that the use of a diet rich in fiber and protein is suitable for performing effective and safe weight loss program. Obese dogs submitted to weight loss showed a significant reduction in systolic blood pressure, glycemia, insulinemia, cholesterolemia, serum alkaline phosphatase and gamma glutamyl transferase activity. 


\section{Acknowledgements}

To the Araucaria Foundation that made this research possible.

\section{References}

[1] Courcier, E.A., Thomson, R.M., Mellor, D.J. and Yam, P.S. (2010) An Epidemiological Study of Environmental Factor Associated with Canine Obesity. Journal of Small Animal Practice, 51, 362-367. https://doi.org/10.1111/j.1748-5827.2010.00933.x

[2] German, A.J., Holden, S.L., Moxham, G.L., Holmes, K.L., Hackett, R.M. and Rawlings, J.M. (2006) A Simple, Reliable Tool for Owners to Assess the Body Condition Is Their Dog or Cat. The Journal of Nutrition, 136, 2031S-2033S. https://doi.org/10.1093/jn/136.7.2031S

[3] Zoran, D.L. (2010) Obesity in Dogs and Cats: A Metabolic and Endocrine Disorder. Veterinary Clinics of North America: Small Animal Practice, 40, 221-239. https://doi.org/10.1016/j.cvsm.2009.10.009

[4] Vasques, A.C., Rosado, L.E.F.P.L., Alfenas, R.C.G. and Geloneze, B. (2008) Critical Analysis on the Use of the Homeostasis Model Assessment (HOMA) Indexes in the Evaluation of the Insulin Resistance and the Pancreatic Beta Cells Functional Capacity. Arquivos Brasileiros de Endocrinologia e Metabologia, 52, 32-39. https://doi.org/10.1590/S0004-27302008000100006

[5] Hoenig, M., Thomaseth, K., Waldron, M. and Ferguson, D.C. (2007) Insulin Sensitivity, Fat Distribution, and Adipocytokine Response to Different Diets in Lean and Obese Cats before and after Weight Loss. American Journal of Physiology. Regulatory, Integrative and Comparative Physiology, 292, R227-R234. https://doi.org/10.1152/ajpregu.00313.2006

[6] Pereira Neto, G.B.P., Brunetto, M.A., Sousa, M.G., Carciofi, A.C. and Camacho, A.A. (2010) Effects of Weight Loss on the Cardiac Parameters of Obese Dogs. Pesquisa Veterinária Brasileira, 30, 167-171. https://doi.org/10.1590/S0100-736X2010000200012

[7] Tvarijonaviciute, A., Cerón, J.J., Holden, S.L., Cuthbertson, D.J., Biourge, V., Morris, P.J. and German, A.J. (2012) Obesity-Related Metabolic Dysfunction in Dogs: A Comparison with Human Metabolic Syndrome. BMC Veterinary Research, 8, 1-8. https://doi.org/10.1186/1746-6148-8-147

[8] Aptekmann, K.P., Suhett, W.G., Mendes Junior, A.F., Souza, G.B., Tristão, A.P.P.A., Adams, F.K., Aoki, C.G., Palacios Junior, R.J.G., Carciofi, A.C. and Tinucci Costa, M. (2014) Nutritional and Environment Aspects of Canine Obesity. Ciência Rural, 44, 2039-2044. https://doi.org/10.1590/0103-8478cr20130524

[9] German, A.J., Holden, S.L., Bissot, T., Hackett, R.M. and Biourge, V. (2007) Dietary Energy Restriction and Successful Weight Loss in Obese Client-Owned Dogs. Journal of Veterinary Internal Medicine, 21, 1174-1180. https://doi.org/10.1111/j.1939-1676.2007.tb01934.x

[10] Weber, M., Bissot, T., Servet, E., Sergheraert, R., Biourge, V. and German, A.J. (2007) A High-Protein, High-Fiber Diet Designed for Weight Loss Improves Satiety in Dogs. Journal of Veterinary Internal Medicine, 21, 1203-1208. https://doi.org/10.1111/j.1939-1676.2007.tb01939.x

[11] German, A.J., Holden, S.L., Bissot, T., Morris, P.J. and Biourge, V. (2010) A High Protein High Fiber Diet Improves Weight Loss in Obese Dogs. The Veterinary Journal, 183, 294-297. https://doi.org/10.1016/j.tvjl.2008.12.004 
[12] Laflamme, D.P. (1997) Development and Validation of a Body Condition Score System for Dogs. Canine Practice, 22, 10-15.

[13] Behrend, E.N., Kooistra, H.S., Nelson, R., Reusch, C.E. and Scott-Moncrieff, J.C. (2013) Diagnosis of Spontaneous Canine Hyperadrenocorticism: 2012 ACVIM Consensus Statement (Small Animal). Journal of Veterinary Internal Medicine, 27, 1-13. https://doi.org/10.1111/jvim.12192

[14] Henik, R.A., Dolson, M.K. and Wenholz, L.J. (2005) How to Obtain a Blood Pressure Measurement. Clinical Techniques in Small Animal Practice, 20, 144-150. https://doi.org/10.1053/j.ctsap.2005.05.005

[15] Brown, S., Elliott, T., Francey, T., Polzin, D. and Vaden, S. (2013) Consensus Recommendations for Standard Therapy of Glomerular Disease in Dogs. Journal of Veterinary Internal Medicine, 27, S27-S43. https://doi.org/10.1111/jvim.12230

[16] Brooks, D., Churchill, J., Fein, K., Linder, D., Michel, K.E., Tudor, K., Ward, E. and Witzel, A. (2014) 2014 AAHA Weight Management Guidelines for Dogs and Cats. Journal of the American Animal Hospital Association, 50, 1-11. https://doi.org/10.5326/JAAHA-MS-6331

[17] Michel, K.E. (2012) Nutritional Management of Body Weight. In: Fascetti, A.J. and Delaney, S.J., Eds., Applied Veterinary Clinical Nutrition, Willey-Blackwell, Iowa, 109-124. https://doi.org/10.1002/9781118785669.ch9

[18] Santos, E.Z., Ferreira, K.C. and Sewastjanow, L. (2014) Avaliação dos parâmetros metabólicos (colesterol, triglicérides, e glicemia), e pressão arterial sistólica em cães obesos: antes e após 30 dias de restrição calórica. In: 35 Congresso Brasileiro da ANCLIVEPA, 2014. Belo Horizonte. Anais do 35 Congresso Brasileiro da Associação Nacional de Clínicos Veterinários de Pequenos Animais. Belo Horizonte: ANCLIVEPA, 0323-0325.

[19] Pérez-Sánches, A.P., Del-Angel-Caraza, J., Quijano-Hernandéz, I.A. and Barbosa-Mireles, M.A. (2015) Obesity-Hypertension and Its Relation to Other Diseases in Dogs. Veterinary Research Communications, 39, 45-51. https://doi.org/10.1007/s11259-015-9630-9

[20] Rocchini, A.P., Moorehead, C., Wentz, E., Deremer, S. (1987) Obesity-induced hypertension in the dog. Hypertension, 9, III-64-III-68.

https://doi.org/10.1161/01.HYP.9.6_Pt_2.III64

[21] Reusch, C.E., Schellenberg, S. and Wenger, M. (2010) Endocrine Hypertension in Small Animals. Veterinary Clinics of North America: Small Animal Practice, 40, 335-352. https://doi.org/10.1016/j.cvsm.2009.10.005

[22] Jeusette, I.C., Lhoest, E.T., Istasse, L.P. and Diez, M.O. (2005) Influence of Obesity on Plasma Lipid and Lipoprotein Concentrations in Dogs. The American Journal of Veterinary Research, 66, 81-86. https://doi.org/10.2460/ajvr.2005.66.81

[23] Verkest, K.R., Rand, J.S., Fleeman, L.M. and Morton, J.M. (2012) Spontaneously Obese Dogs Exhibit Greater Postprandial Glucose, Triglyceride, and Insulin Concentrations than Lean Dogs. Domestic Animal Endocrinology, 42, 103-112. https://doi.org/10.1016/j.domaniend.2011.10.002

[24] Mori, N., Lee, P., Kondo, K., Kido, T., Saito, T. and Arai, T. (2011) Potential Use of Cholesterol Lipoprotein Profile to Confirm Obesity Status in Dogs. Veterinary Research Communications, 35, 223-235. https://doi.org/10.1007/s11259-011-9466-X

[25] Kutsunai, M., Kanemoto, H., Fukushima, Y., Fujino, Y., Ohno, K. and Tsujimoto, H. (2014) The Association between Gall Bladder Mucoceles and Hyperlipidaemia in Dogs: A Retrospective Case Control Study. The Veterinary Journal, 199, 76-79. https://doi.org/10.1016/j.tvjl.2013.10.019 
[26] Nelson, R.W., Delaney, S.J. and Elliott, D.A. (2010) Distúrbios Metabólicos. In: NELSON RW, COUTO CG. Medicina Interna de Pequenos Animais. 4th Edition, Elsevier, Rio de Janeiro, 853-865.

[27] Gayet, C., Bailache, E., Dumon, H., Martin, L., Siliart, B. and Nguyen, P. (2004) Insulin Resistance and Changes in Plasma Concentration of TNFa, IGF1, and NEFA in Dogs during Weight Gain and Obesity. Journal of Animal Physiology and Animal Nutrition, 88, 157-165. https://doi.org/10.1111/j.1439-0396.2003.00473.x

[28] Kawasumi, K., Suzuki, T., Fujiwara, M., Mori, N., Yamamoto, I. and Arai, T. (2012) New Criteria of Hyperlipidemia with Insulin Resistance in Dogs. Journal of Animal and Veterinary Advances, 11, 3950-3952.

[29] Verkest, K.R., Fleeman, L.M., Morton, J.M., Ishioka, K. and Rand, J.S. (2011) Compensation for Obesity-Induced Insulin Resistance in Dogs: Assessment of the Effects of Leptin, Adiponectin, and Glucagon-Like Peptide-1 Using Path Analysis. Domestic Animal Endocrinology, 41, 24-34.

https://doi.org/10.1016/j.domaniend.2011.02.001

[30] Verkest, K.R., Rand, J.S., Fleeman, L.M., Richards, A.A., Rose, F.J. and Whitehead, J.P. (2011) Distinct Adiponectin Profiles Might Contribute to Differences in Susceptibility to Type 2 Diabetes in Dogs and Humans. Domestic Animal Endocrinology, 41, 67-73. https://doi.org/10.1016/j.domaniend.2011.03.003 